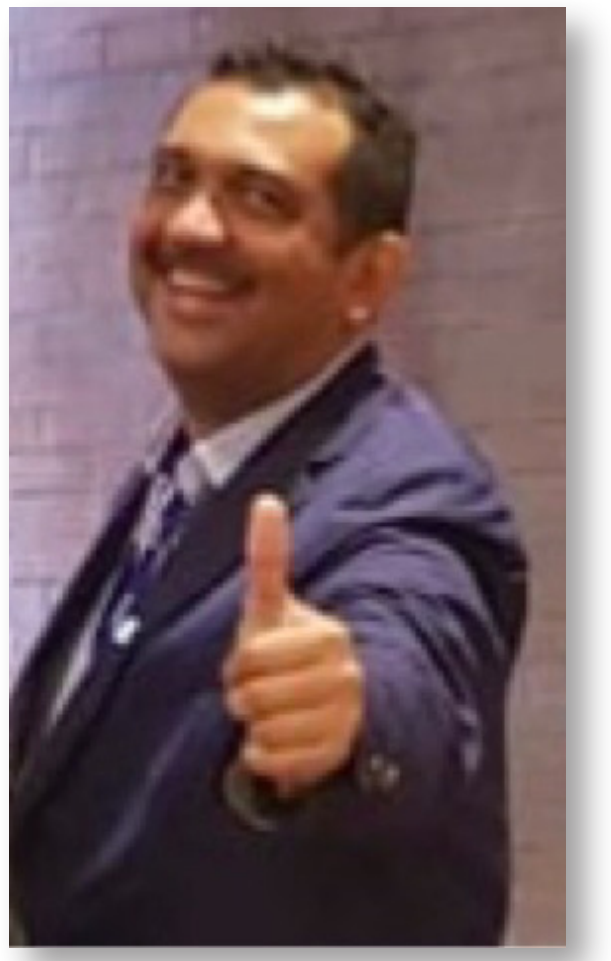

\title{
Dr. Virgil Carballo Zárate (1964-2020)
}

- Oiga prafe, y recibiá las charlas?

- Na. Me enviaste fue la de remadelada cardiaca.

Ya quiera la de insuficiencia cardiaca para tamar unas imágenes para la clase que le vay a dar a las estudiantes de sexta y la atra de dulaglutide para revisar unas datas que me parecieran interesantes....

- Prafe esa es que Sandra na ha padida, pera na se preacupe que ya las pasa a una memaria y se la deja en su edificia

\section{Domingo 23 de agosto}

Fue la última conversación que tuvimos.

El lunes 24 a 9 pm me llamó otra de mis tantos hijos que me han regalado los 40 años de docencia en aulas y salas de hospital. 
- Profe! Profe! Virgil no me contesta.............

- Calma Angelita el salió de alta hoy y seguro está disfrutando su cama y almohada, después de una semana en la clínica...

En la madrugada me enteraría que lo habían llevado a UCI de Medihelp y entonces supe en un instante, que las Parcas lo buscaban, pero como médico al fin me negué a aceptar tan ominoso pensamiento y me remití a la mitología y asumí que nuestros colegas podrían aguantar las tijeras de Atropos, la cortavidas y dejar que Cloto y Láquesis se la rehicieran. Pronto el pesimismo me abrumó hasta el pasado viernes 4 , cuando la eucaristía de esa noche me devolvió el optimismo, que sólo me duró hasta la noche del domingo 6, cuando comprendí el final.

Virgil Carballo-Zárate fue el mejor bachiller de su promoción en el colegio Comfenalco de Cartagena, en 1981 y al año siguiente ingresó a nuestra alma mater egresando en 1989 como Médico, para volver en busca de su sueño de ser Internista en 1991 y graduarse como tal en 1994; dando inicio a un ejercicio profesional cada día más meritorio.

Lo conocí en 1983 cuando llegó al departamento como estudiante de semiología, pero sería algún día de 1991 cuando lo empezaría a apreciar, durante su residencia en medicina interna.

Y poco después de graduado de internista, se fue acercando a mí persona hasta convertirse en el compañero y amigo de tantas horas. Pero sería en noviembre pasado cuando la Sociedad Argentina de Medicina, (SAM) me concedió el título de Mentor que, él al presentarme, confesaría que en VI semestre cuando le correspondió rotar conmigo, "me había asumido en forma platónica, como su mentor"

"Hicimos camino al andar" cómo dice Machado, un camino marcado por su picaresca manera de acercarse a los temas sobre la mesa, una gran facilidad para simplificar discusiones con el sello inconfundible de su sonrisa, mezcla de espontánea alegría y sobrada humildad.

En esos tiempos de los 90 y para nuestras fiestas patrias, siendo yo secretario ejecutivo del club de Profesionales Universitarios de Cartagena, le dije: Virgil, una hija putativa quiere que la lleve a la fiesta de gala con las candidatas al reinado nacional de la belleza y me pidió que le escogiera el parejo y ese eres tú.... Listo profe deme las señas y yo voy. Y así fue y este niño grande resulto algo negado para la danza pero bueno para la "parla, el chiste y la risa" de modo que la pareja se lo aguantó hasta la madrugada.

Muchos años después comprendería el por qué.

En efecto, en cualquier momento le dije, Virgil de quien es esto:

$$
\begin{aligned}
& \text { "El alma muere derratada } \\
& \text { Desesperada en el dalar..." }
\end{aligned}
$$

Y el continuó:

$$
\begin{gathered}
\text { Sacrificada sin razán } \\
\text { Sin un amar na hay saluación } \\
\text { Na me dejes de querer } \\
\text { Te pida" }
\end{gathered}
$$

- Sin un amor, de Los Panchos, dijo y es que él tenía una gran facilidad para recordar las letras y las melodías de muchísimas canciones de todo género y tatarearlas. Conocía bien las bandas sonoras más famosas y Enrio Morricone, su preferido. Era un poco común caso de equilibrio por lo alto entre ambos hemisferios cerebrales. Era un zurdo veloz!

Pero Virgil vivía de prisa, cómo si supiera que se le agotaba el tiempo. A principios de este año le pregunté: - Virgil 6 de mayo congreso paraguayo y 8 el de dominicana, cómo hacemos? Tú a uno y yo al otro?

- no profe, debemos cumplirle a los dos, búsquese una salida

Y bueno la solución propuesta y acogida fue: salimos el lunes 4 y amanecemos en Asunción, ese día 5, la inauguración, el 6 las charlas y el 7 volamos directo a Punta Cana, el 8 damos las charlas y el 9 regresamos. Llegar a dormir para madrugar el lunes a trabajar. Pero la pandemia no lo permitió.

Ese ritmo le encantaba y realmente lo hicimos divertido. Durante los vuelos si no dormía, me acosaba a preguntas sobre mis profesores y mis experiencias, tratando a la manera de un historiador, de comprender el presente. 
Otras veces me planteaba sus preocupaciones y en ocasiones me exigía una opinión, que casi siempre acogía y luego aplicaba si era menester. Fue un hombre que sabía escuchar y lo hacía sin demostrar emociones.

Su pasión por la medicina interna no tuvo límites, consulta externa, urgencia, UCI y salas de internación fueron escenarios de un ejercicio sabio y prudente enmarcado en la ética y con abrumadora sencillez.

Durante los últimos 10 años ejerció con solvencia la docencia en el Departamento Médico de la Universidad de Cartagena, su alma mater. Era de escrupuloso cumplimiento; en varias ocasiones al aterrizar de vuelta de los innumerables viajes que hicimos juntos, me decía mientras recogíamos el equipaje: ... ya los estudiantes están esperándome en Zaragocilla, al otro lado de la ciudad, (sede de la Facultad de Medicina de la Universidad de Cartagena y del Hospital Universitario)

- Cómo dices Virgil?, hoy es viernes y son las 5 de la tarde...

- así es profe pero fue lo que acordamos con los muchachos

Y cumplía su tarea

Durante mi presidencia de ACMI, elaboré un proyecto de ley para regular nuestra especialidad y él me acompañó como siempre, pero con medido entusiasmo y tuvo razón, poco a poco se murió en el Capitolio. Estuvo al tanto de cada fracaso; liberales, conservadores, la U y el centro democrático, sencillamente decepcionantes. Y ello lo fue llevando a situarse cada vez más en la orilla de las reinvindicaciones: "yo no puedo entender cómo aceptan -los médicos- trabajar con pago a 8 meses y la energía, el agua, los colegios y los bancos, tenemos que pagarlos mes a mes".
En enero de este año me dijo: "prepárese que tan pronto deje la presidencia vamos a meterle el hombro al sindicato y a las contrataciones legales"

La pandemia lo hizo adelantarse y alzó su voz para denunciar con claridad y sin exageraciones, la tragedia en que se ha convertido el ejercicio de la medicina en general y la medicina interna en particular.

Tal vez, esta fue su última y sentida preocupación.

\section{Pero ¿por qué, Virgil?}

Es un gran interrogante que nos hacemos siempre que perdemos a un ser querido y más aún, cuando consideramos que no es candidato aún para morir.

Virgil Carballo Zárate fue un ser humano de gran espiritualidad, pero silenciosa, de hechos y no palabras. Quizá sin saberlo se había distanciado del "Serpara-la-muerte" de Heidegger y los existencialistas para vivir como un "Ser-a-pesar - de-la-muerte", un "Ser-para-el-prójimo"; a la manera de Lévinas.

A Sandra, la pediatra de este "niño grande" que fue Virgil toda nuestra solidaridad, deseándole fortaleza y cristiana resignación; a Daniel "el travieso" y a Juan José "el artista" les digo: a cumplir todo lo hablado y planeado con su padre.

Colegas y amigos y amigas todos "la muerte incorpora de alguna manera el ausente a la historia" dice Ricoeur, Virgil ya lo está en la de la Medicina y la de todos nosotros.

Muchas gracias !!!

Heli Hernández-Ayazo

Cartagena, 15 de septiembre 2020

Dr. Helí Hernández Ayazo: Especialista en Clínica Médica/Medicina Interna, PHD en Ciencias de la Educación-Historia de la Medicina, Profesor Titular de Medicina Universidad de Cartagena, Internista de consulta Hospital Universitario del Caribe. Cartagena (Colombia).

E-mail: helihernandezayazo@gmail.com 